\title{
In vitro antioxidant activity of crude extracts of Harpagophytum zeyheri and their anti-inflammatory and cytotoxicity activity compared with diclofenac
}

Sibonokuhle F. Ncube ${ }^{1 *}$, Lyndy J. McGaw², Emmanuel Mfotie Njoya ${ }^{2,3}$, Hilton G. T. Ndagurwa ${ }^{1,4}$, Peter J. Mundy ${ }^{1}$ and Samson Sibanda ${ }^{5}$

\begin{abstract}
Background: This study evaluated the in vitro antioxidant activity and comparison of anti-inflammatory and cytotoxic activity of Harpagopytum zeyheri with diclofenac.

Methods: In vitro assays were conducted using water, ethanol, and ethyl acetate extracts of H.zeyheri. The antioxidant activity was evaluated using the 2,2'-diphenyl-1-picrylhydrazy (DPPH) and 2,2'- azino-bis (3ethylbenzothiazoline-6-sulphonic acid) (ABTS) assays. The anti-inflammatory activity was determined by measuring the inhibition of nitric oxide (NO) on lipopolysaccharide (LPS)-induced RAW 264.7 mouse macrophages as well as cytokine (TNF-a and IL-10) expression on LPS-induced U937 human macrophages. For cytotoxicity, cell viability was determined using the 3-(4, 5-dimethylthiazol- 2-yl)-2,5-diphenyl tetrazolium bromide (MTT) assay.

Results: The ethyl acetate extract had the lowest $I C_{50}$ values in the DPPH $(5.91 \mu \mathrm{g} / \mathrm{ml})$ and ABTS $(20.5 \mu \mathrm{g} / \mathrm{ml})$ assay compared to other extracts. Furthermore, the ethyl acetate extracts effectively inhibited NO and TNF-a and proved to be comparable to diclofenac at some concentrations. All extracts of $H$. zeyheri displayed dose-dependent activity and were associated with low levels of human-IL-10 expression compared to quercetin. Furthermore, all extracts displayed low toxicity relative to diclofenac.
\end{abstract}

Conclusions: These findings show that $H$. zeyheri has significant antioxidant activity. Additionally, similarities exist in the inflammatory activity of $\mathrm{H}$. zeyheri to diclofenac at some concentrations as well as low toxicity in comparison to diclofenac.

Keywords: Antioxidant, Cytotoxicity, Cytokines, Harpagophytum zeyheri, Inflammation, Nitric oxide

\section{Background}

Inflammation occurs in the body as a response to infection, injury, and other harmful stimuli $[35,36]$, which is related to the excess production of free radicals such as

\footnotetext{
* Correspondence: sibonokuhle.ncube@nust.ac.zw

'Department of Forest Resources and Wildlife Management, Faculty of Applied Science, National University of Science and Technology, P. O. Box AC 939, Ascot, Bulawayo, Zimbabwe

Full list of author information is available at the end of the article
}

superoxide, hydroxyl, and peroxyl in the body resulting in damaging effects. Complex interactions occur between mediators of inflammation and inflammatory cells during inflammation [44] triggering the release of signalling molecules and enlistment of circulating leucocytes such as macrophages. These become stimulated at the area of inflammation, thereby releasing various types of mediators and cytokines with either pro- or antiinflammatory action, such as nitric oxide (NO), Tumor

(c) The Author(s). 2021 Open Access This article is licensed under a Creative Commons Attribution 4.0 International License, which permits use, sharing, adaptation, distribution and reproduction in any medium or format, as long as you give appropriate credit to the original author(s) and the source, provide a link to the Creative Commons licence, and indicate if changes were made. The images or other third party material in this article are included in the article's Creative Commons licence, unless indicated otherwise in a credit line to the material. If material is not included in the article's Creative Commons licence and your intended use is not permitted by statutory regulation or exceeds the permitted use, you will need to obtain permission directly from the copyright holder. To view a copy of this licence, visit http://creativecommons.org/licenses/by/4.0/. The Creative Commons Public Domain Dedication waiver (http://creativecommons.org/publicdomain/zero/1.0/) applies to the data made available in this article, unless otherwise stated in a credit line to the data. 
Necrosis Factor (TNF- $\alpha$ ), prostaglandins (PG), and interleukins IL-6, IL-10, and IL-1 $\beta$ [49]. Inflammation and inflammation cell interactions result in either a positive outcome of host-defense mechanism or in uncontrolled cases, lead to tissue injury and chronic diseases [26] with studies showing that in almost 99\% of cases, inflammations are intolerable if not treated properly [4].

TNF- $\alpha$ is an essential factor for the stimulation of the genetic expression of inducible nitric oxide synthase (iNOS) in various cell lines [47]. Nitric oxide produced in large amounts by one of the pro-inflammatory enzymes, iNOS, is known to be responsible for the vasodilation and hypotension observed during septic shock and inflammation [48]. In addition, excessive NO production is found in many inflammation-related diseases such as asthma, arthritis, and multiple sclerosis. Signalling molecules released during inflammation may also interact with free radicals causing irreversible damage to cell membranes leading to cell death and tissue damage [46]. All related inflammatory mediators play a role in the genesis and progression of the various inflammatory diseases [38]. Thus, because of the implications of inflammation in chronic diseases, there is high demand for treatment, with Non-Steroidal Anti-Inflammatory Drugs (NSAIDs) which are among the most used medications [24]. Most drugs used for inflammatory diseases act by suppressing levels of pro-inflammatory cytokines, iNOS, prostaglandins, cyclooxygenases, and lipoxygenases [33]. Despite the effectiveness of these drugs, their safety is a cause for concern with studies linking almost $90 \%$ of them with related toxicities and side effects [25], which has resulted in growing research on natural therapies for inflammation that are deemed safer but still provide the necessary relief.

Diclofenac is one such NSAID, which despite its effectiveness, notable side effects such as gastric irritation, ulceration, bleeding, renal failure, and hepatic failure among many others have been highlighted [19]. Other indirect side effects of diclofenac include serious ecological impacts such as the catastrophic decline in vulture populations in the Indian subcontinent which has negative consequences on the environment [30, 40]. Thus, studies on medicinal plants with similar properties as synthetic drugs, are becoming increasingly important as they are deemed safer alternatives, and research is focused on this topic worldwide (reviewed in [7]).

The Pedaliaceae family has the Harpagophytum genus which consists of two species: Harpagophytum procumbens (Burch. 1822) D.C. ex Meissn. and Harpagophytum zeyheri (Decne. 1865). Due to the close taxonomic similarities of the two species, they are both loosely referred to as Devil's Claw or grapple plant, a common name derived from the hooked formation of the fruit giving it a claw-like appearance [45]. As an adaptation to the arid
Kalahari sands, both plants consist of a tuberous taproot with secondary tubers developing on fleshy roots which grow from the primary tuber [43]. The secondary tubers contain iridoid glycosides, with harpagoside as the main active ingredient, which enables the use of the plants for medicinal purposes, particularly for treating rheumatism, arthritis, digestive disorders, sores, ulcers, and boils [37, 45]. As a result, Devil's Claw is commercially exploited for its medicinal properties which contribute significantly to the health, livelihoods, and economies of rural communities in southern Africa [21, 41]. Most research on Devil's Claw has focused on $H$. procumbens $[1,5,16$, 20, 27] and less attention has been paid to $H$. zeyheri. According to [31], the medicinal value of $H$. zeyheri remains uncertain despite its usage and commercialisation. This suggests the need for detailed profiling of the medicinal properties of $H$. zeyheri if the medicinal potential of this species is to be fully realised.

To this end, we examined the biological activity of $H$. zeyheri subspecies sublobatum (hereafter referred to as $H$. zeyheri). The findings of this study have significant ramifications on the perceptions and commercial value as well as conservation of $H$. zeyheri. In Zimbabwe, $H$. zeyheri is patchily distributed in the western parts of the country, including the Hwange District where it is commercially exploited by local communities [42], which offers an opportunity to examine the biological activity of the plant under commercial exploitation. Therefore, the objectives of this study were to determine a) antioxidant activity, b) anti-inflammatory and c) cytotoxic activity of crude extracts of $H$. zeyheri. The anti-inflammatory and cytotoxic activity were further compared to diclofenac.

\section{Methods}

\section{Collection of plant material}

H. zeyheri tubers were collected in Hwange District, northwest Zimbabwe, in July 2016 after seeking permission from the Hwange Rural District Council and local community leadership. Plant identification was done by Anthony Mapaura, Senior Research Officer at the National Herbarium and Botanic Gardens of Zimbabwe, and a voucher specimen is deposited there (Voucher: CASSRGH108539).

\section{Extraction}

Preparation of the sample included washing, slicing, and air drying of the tubers at room temperature $\left(25^{\circ} \mathrm{C}\right)$ over 5-8 days. Extraction was done guided by Do et al. [13], with minor modifications. The dried tubers were ground into powder and $10 \mathrm{~g}$ of powder were placed in $100 \mathrm{ml}$ of each of 3 different solvents (ethyl acetate, ethanol, and water). The mixtures were left for $24 \mathrm{~h}$ (h) at room temperature. The extracts were then filtered, and the filtrates were left standing at room temperature for 24 to 
$48 \mathrm{~h}$ to dry to a sticky or powdery substance [22]. Water extracts were evaporated at $55^{\circ} \mathrm{C}$ in a ventilated oven for up to 4 days. All the crude extracts were then stored at $4{ }^{\circ} \mathrm{C}$ in a cold room until use.

\section{Antioxidant activity}

The extracts of $H$. zeyheri were subjected to screening for antioxidant activity by two methods namely DPPH and ABTS free radical scavenging.

\section{DPPH radical scavenging assay}

The determination of the DPPH free radical scavenging activity of the crude extracts was done using the Shimada et al. [39] method, with a few modifications. The crude extracts $(40 \mu \mathrm{L})$ were serially diluted in methanol in a 96-well plate followed by the addition of a DPPH solution $(160 \mu \mathrm{L})$ freshly prepared at $25 \mu \mathrm{g} / \mathrm{ml}$ in methanol. The plates were incubated at room temperature $\left(25^{\circ} \mathrm{C}\right)$ in the dark for $30 \mathrm{~min}$ and the absorbance was measured on a microplate reader (Epoch, Biotek) at the wavelength of $517 \mathrm{~nm}$ [39]. The radical scavenging activity was calculated by the following equation:

$$
\begin{aligned}
& \text { DPPH radical scavenging }(\%) \\
& =\frac{\left(\mathrm{A}_{0}-\mathrm{A}_{1}\right)}{\mathrm{A}_{0}} \times 100
\end{aligned}
$$

where $A_{0}$ is the absorbance of the control and $A_{1}$ is the absorbance of the sample.

Ascorbic acid was used as the positive control while the mixture of methanol with DPPH solution was used as the negative control. The blanks were made of methanol and extracts. The $\mathrm{IC}_{50}$ values were calculated as the concentration of sample required to scavenge $50 \%$ of $\mathrm{DPPH}$ free radicals.

\section{$A B T S$ radical scavenging assay}

The determination of ABTS radical scavenging activity was done using the ABTS cation decolourisation assay described by Re et al. [34], with a few modifications. The ABTS radical cation $\left(\mathrm{ABTS}^{*+}\right)$ was produced by the reaction of a $7 \mathrm{mM}$ stock solution of ABTS with $2.45 \mathrm{mM}$ potassium persulphate and allowing the mixture to stand in the dark at room temperature for $12-16 \mathrm{~h}$ before use. The $\mathrm{ABTS}^{*+}$ solution was diluted with methanol to give an absorbance of $0.70 \pm 0.01$ at $734 \mathrm{~nm}$ [34]. Each plant extract $(40 \mu \mathrm{L})$ was serially diluted in a 96 -well plate and then allowed to react with $160 \mu \mathrm{L}$ of the $\mathrm{ABTS}^{*+}$ solution. After $6 \mathrm{~min}$, the absorbance was measured at 714 $\mathrm{nm}$ [34]. Trolox and ascorbic acid were used as positive controls while the mixture of methanol and ABTS ${ }^{+}$ solution was used as the negative control. The blanks were made of methanol and extracts. Percentage ABTS inhibition was expressed as a percentage following Eq. 1 above. Both the ABTS and DPPH assays were conducted at concentrations 400,200, 100, 50, 25, 12.5, and $6.25 \mu \mathrm{g} / \mathrm{ml}$.

\section{Anti-inflammatory activity}

The anti-inflammatory activity of $H$. zeyheri extracts was examined by testing NO inhibition and cytokine expression of both TNF- $\alpha$ and IL-10 in mouse and human macrophage cells.

\section{Nitric oxide production inhibitory assay in mouse RAW 264.7 macrophage cells}

The mouse RAW 264.7 macrophage cells were purchased from the American Type Culture Collection (ATCC, Rockville, MD, USA) and cultured in a plastic culture flask in Dulbecco's Modified Eagle's Medium (DMEM) containing L-glutamine (HycloneTM) and supplemented with $10 \%$ foetal bovine serum (FBS) (Capricorn Scientific Gmbh, South America) and 1\% penicillin/streptomycin/fungizone (PSF) solution at $37^{\circ} \mathrm{C}$ with $5 \% \mathrm{CO}_{2}$. The cells were seeded $(10,000$ cells per well) in 96 well-microtitre plates and allowed to attach overnight. The cells were then treated simultaneously with LPS alone (control) and extract at different concentrations. Quercetin and diclofenac were used as the positive controls.

The amount of nitrite produced was determined as described by Dzoyem et al. [14]. Then after $24 \mathrm{~h}$ of incubation at $37^{\circ} \mathrm{C}$ with $5 \% \mathrm{CO}_{2}, 100 \mu \mathrm{L}$ of cell supernatant from each well were transferred into a new 96-well microtiter plate and the same volume of Griess reagent was added. After $15 \mathrm{~min}$ of incubation in the dark at room temperature $\left(25^{\circ} \mathrm{C}\right)$, the absorbance was recorded at $550 \mathrm{~nm}$ on a microtiter plate reader (Epoch Biotek) [14]. The percentage of NO inhibition was calculated based on the ability of extracts to inhibit nitric oxide production by RAW 264.7 macrophage cells compared with the control (cells treated with LPS alone without samples).

\section{Determination of cytokine expression in human U937 macrophage cells}

To prepare the cells, the method described by Passmore et al. [32] with minor modifications was used. The U937 macrophage cells from the American Type Culture Collection (ATCC, Rockville, MD, USA) were maintained in a humidified atmosphere at $37{ }^{\circ} \mathrm{C}$ with $5 \% \mathrm{CO}_{2}$ in Roswell Park Memorial Institute (RPMI-1640) medium containing L-glutamine (Lonza, SA) and supplemented with $10 \%$ foetal bovine serum (FBS) (Capricorn Scientific Gmbh, South America) and 1\% penicillin/streptomycin/ fungizone (PSF) solution. The cells were seeded $(500,000$ cells per well) in a 6-well microtitre plate and treated 
with LPS alone (control) and extracts at different concentrations [32]. Quercetin, a flavonoid found in plants with known anti-inflammatory properties, and diclofenac were used as the positive controls.

\section{Determination of the cell viability}

The cell viability was determined to establish whether the inhibition of NO production, inhibition of TNF- $\alpha$ and expression of IL-10 by extracts were not due to their cytotoxic effects. The cytotoxicity of crude extracts was determined using the 3-(4,5-dimethylthiazol- 2-yl)-2,5diphenyl tetrazolium bromide (MTT) assay as described by Mosmann [29]. After each of the assays, the culture medium was removed from the plates and after washing with $200 \mu \mathrm{L}$ of phosphate-buffered saline (PBS), $200 \mu \mathrm{L}$ of fresh culture medium and $30 \mu \mathrm{L}$ of MTT solution (5 $\mathrm{mg} / \mathrm{mL}$ ) were added to all wells and the plates were incubated at $37^{\circ} \mathrm{C}$ with $5 \% \mathrm{CO}_{2}$ for $4 \mathrm{~h}$. After incubation, the culture medium was carefully aspirated using a suction pump (Integra, USA), and $50 \mu \mathrm{L}$ of dimethylsulphoxide (DMSO) was added to all wells. The absorbance was read using a microplate reader (Biotek Synergy, USA) at a wavelength of $570 \mathrm{~nm}$ and a reference wavelength of $630 \mathrm{~nm}$. The percentage of cell viability was calculated by comparing the absorbance of the samples to the negative control (cells treated only with LPS considered as $100 \%$ viability) [29].

\section{Determination of inhibitory concentration $\left(I C_{50}\right)$ and statistical analysis}

All experiments were carried out in triplicates and results are presented as mean \pm standard deviation. The $\mathrm{IC}_{50}$ value of tested samples, which represent the concentration of the sample required to inhibit $50 \%$ of the activity compared to the negative control, was determined by using a non-linear regression curve of the percentage of inhibition against the logarithm of concentrations. The extracts with lower $\mathrm{IC}_{50}$ values show the high activity of the extract or compound. A one-way analysis of variance (ANOVA) was used to test for differences in the measured variables between extracts. All statistical calculations were conducted using $\mathrm{R}$ version 3.5.3 with an accepted significance of $p<0.05$ in all tests.

\section{Results}

\section{Antioxidant activity of crude extracts}

Crude extracts of Harpagophytum zeyheri had varying antioxidant activities with significant differences $(p<$ 0.001) between samples (Table 1). The highest DPPH radical-scavenging activities of extracts were displayed by the ethyl acetate extract closely followed by the ethanol extract $\left(\mathrm{IC}_{50}\right.$ value $<32 \mu \mathrm{g} / \mathrm{ml}$; Table 1$)$. The water extracts had no activity in both assays $\left(\mathrm{IC}_{50}\right.$ value >
$100 \mu \mathrm{g} / \mathrm{ml}$; Table 1). The extracts showed concentrationdependent activity, with a gradual increase in activity in the water extract relative to the rapid activity of the other extracts (Fig. 1).

The $\mathrm{IC}_{50}$ values of crude extracts in the ABTS assay ranged from $12.56 \mu \mathrm{g} / \mathrm{ml}$ to $127.89 \mu \mathrm{g} / \mathrm{ml}$. Good radical scavenging activity in the ABTS assay was displayed by the ethyl acetate and ethanol extracts which had the lowest $\mathrm{IC}_{50}$ values of $12.56 \mu \mathrm{g} / \mathrm{ml}$ and $19.59 \mu \mathrm{g} / \mathrm{ml}$, respectively (Table 1 ). The water extract had an $\mathrm{IC}_{50}$ value greater than $100 \mu \mathrm{g} / \mathrm{ml}$ showing no antioxidant activity in the ABTS assay (Table 1). There was a rapid increase in activity in the ABTS assay with an increase in extract concentration (Fig. 2). Like the DPPH assay, the water extract showed a gradual increase in activity with an increase in concentration (Fig. 2).

Anti-inflammatory activity through nitric oxide inhibition The findings showed that nitric oxide inhibition was exhibited only by the ethyl acetate and ethanol extracts (all with $\mathrm{IC}_{50}$ values $<100 \mu \mathrm{g} / \mathrm{mL}$ ), in contrast to the water extract which showed no inhibition (Table 2). Overall, the inhibitory effect of the extracts was weaker relative to diclofenac and the positive control, quercetin $(p<$ 0.05; Table 2). All extracts displayed a dose-dependent inhibition, with high NO inhibition at high concentrations $(100,50$, and 25$)$ not significantly different with diclofenac and quercetin in the case of the ethyl acetate and ethanol extract $(p>0.05$; Table 3$)$.

\section{Modulatory effect of crude extracts on cytokine expression and cell viability on human U937 macrophage cells}

The inhibition of pro-inflammatory cytokines is a good trait for a sample targeted for reducing inflammation. The highest inhibition of the TNF- $\alpha$ cytokine was displayed by the ethyl acetate extract while the water and ethanol extracts showed limited inhibition (Table 4). A comparison of the ethyl acetate extract against the synthetic drug diclofenac showed no significant differences

Table 1 Mean ( \pm standard deviation) $I C_{50}$ values of antioxidant activity of crude extracts of $H$. zeyheri compared to their respective positive controls

\begin{tabular}{lll}
\hline Extract & $\begin{array}{l}\text { Antioxidant } \\
\text { DPPH }\end{array}$ & ABTS \\
\hline Ethyl acetate & $27.40 \pm 0.29^{\mathrm{a}}$ & $12.56 \pm 0.09^{\mathrm{a}}$ \\
Ethanol & $32.09 \pm 0.73^{\mathrm{b}}$ & $19.59 \pm 0.49^{\mathrm{b}}$ \\
Water & $143.20 \pm 0.26^{\mathrm{c}}$ & $127.89 \pm 0.39^{\mathrm{c}}$ \\
Ascorbic Acid & $19.67 \pm 0.67^{\mathrm{d}}$ & $7.16 \pm 0.33^{\mathrm{d}}$ \\
Trolox & $3.18 \pm 0.42^{\mathrm{e}}$ & $10.69 \pm 0.58^{\mathrm{e}}$ \\
\hline
\end{tabular}

Values with different superscript letters in each column are significantly different at $p<0.05$ 


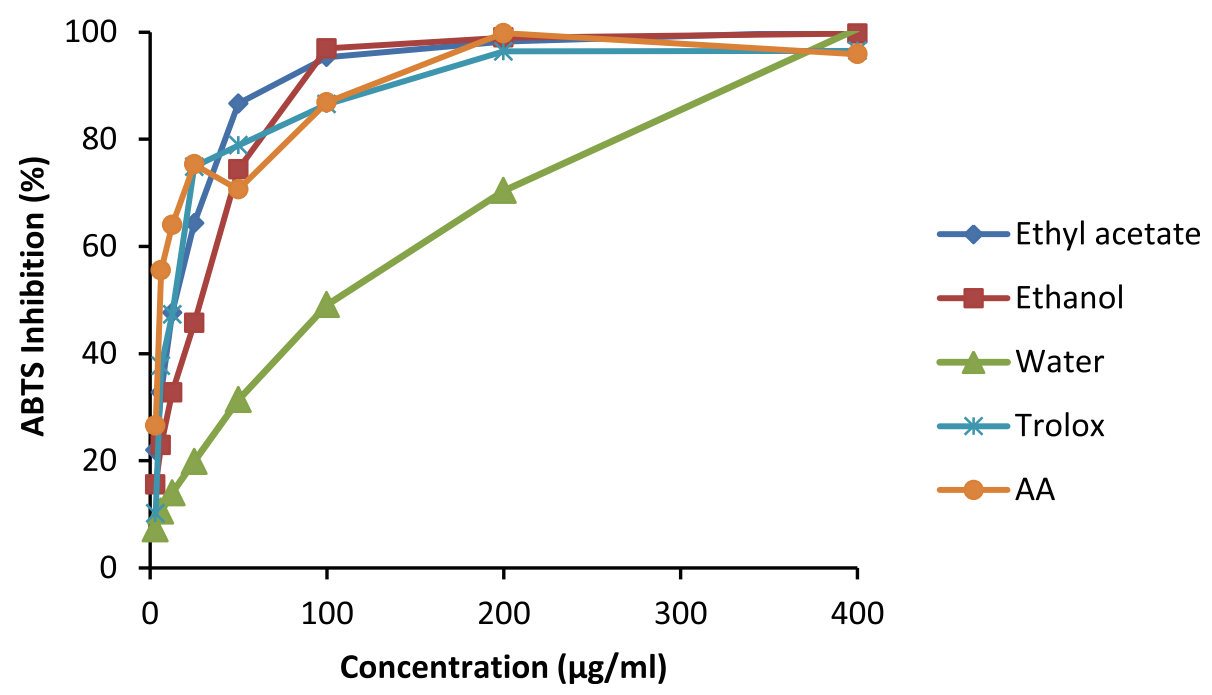

Fig. 1 Antioxidant activity of crude extracts of H. zeyheri using ABTS assay at various concentrations (400, 200, 100, 50, 25, 12.5, and 6.25 $\mu \mathrm{g} / \mathrm{ml})$

in their inhibitory effect $(p>0.05$; Table 4$)$. However, the ethyl acetate extract showed better inhibition of TNF- $\alpha$ than the positive control, quercetin (Table 4). The expression of the cytokine IL-10, an antiinflammatory cytokine, was also examined and only the positive control quercetin encouraged the expression of this cytokine (Table 4). Extracts of $H$. zeyheri and diclofenac had very low levels of human IL-10 expression (Table 4).

\section{Cytotoxicity}

The extracts generally had limited toxicity relative to diclofenac and quercetin (Table 3). The extract with generally the highest inhibitory effect, ethyl acetate, displayed the highest viability of cells $(60 \%)$ at the highest concentration in comparison with diclofenac (1.12\%) and quercetin (28\%). In general, diclofenac had the highest cell toxicity even at the lowest concentrations (Table 3 ). Consequently, the cells which were subjected to the crude extracts are more viable compared to those subjected to diclofenac at the lowest concentrations.

However, despite having a low expression of human IL-10, the plant extracts had limited toxicity on the cells relative to diclofenac and quercetin (Table 4). Cell viability at $50 \mu \mathrm{g} / \mathrm{ml}$ sample concentration was $>90 \%$ in the plant extracts compared to 25 and $50 \%$ with diclofenac and quercetin, respectively.

\section{Discussion}

In the present study, $H$. zeyheri had significant antioxidant, anti-inflammatory, and less cytotoxic properties relative to diclofenac and quercetin. These findings are

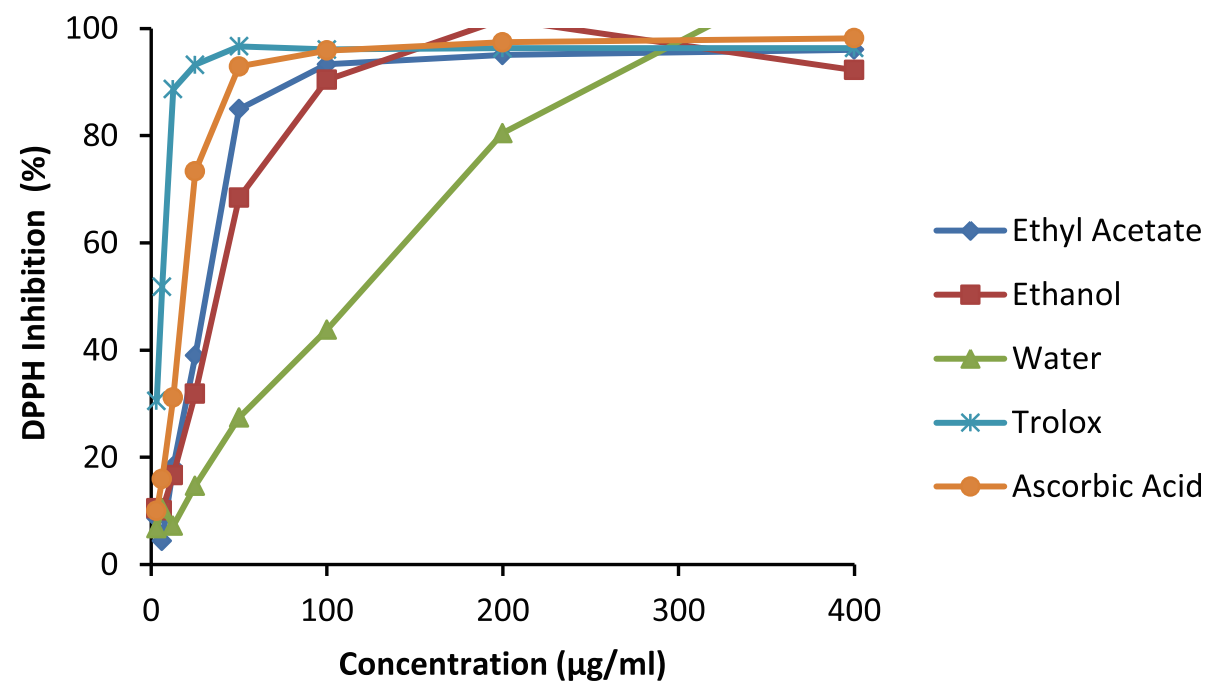

Fig. 2 Antioxidant activity of crude extracts of H. zeyheri using the DPPH assay at various concentrations (400, 200, 100, 50, 12.5, and 6.25 $\mu \mathrm{g} / \mathrm{ml}$ ) 
Table 2 Mean ( \pm standard deviation) $I C_{50}$ values of antiinflammatory activity of crude extracts of $\mathrm{H}$. zeyheri compared to their respective positive controls

\begin{tabular}{ll}
\hline Extract & Anti-inflammation \\
& NO \\
\hline Ethyl acetate & $72.80 \pm 4.53^{\mathrm{a}}$ \\
Ethanol & $92.70 \pm 3.26^{\mathrm{a}}$ \\
Water & $184.53 \pm 4.45^{\mathrm{b}}$ \\
Diclofenac & $10.32 \pm 0.54^{\mathrm{c}}$ \\
Quercetin & $18.10 \pm 0.16^{\mathrm{c}}$ \\
\hline
\end{tabular}

Values with different superscript letters in each column are significantly different at $p<0.05$

consistent with findings by other studies $[3,20]$ which indicated that $H$. zeyheri has significant analgesic and anti-inflammatory properties like the well-studied $H$. procumbens. In this regard, our findings contradict assertions by Chantre et al. [9], stating $H$ zeyheri as not having ethnobotanical relevance and only good as food for insect larvae!

To the best of our knowledge, there is limited work that has been conducted on $H$. zeyheri.. The focus has mainly been on $H$. procumbens which has been deemed as the more medicinally active species in the Harpagophytum genus. Related studies on crude extracts of $H$. procumbens showed significant antioxidant activity of $H$ procumbens and good radical scavenging demonstrated by the methanolic extract [18] and by aqueous extracts containing $2.6 \%$ harpagoside [15]. The results of this study showed strong antioxidant activity for ethyl acetate extracts of $H$. zeyheri in both the DPPH and ABTS assay $\left(\mathrm{IC}_{50}\right.$ value $<27 \mu \mathrm{g} / \mathrm{ml}$ ) but was lower than that of Trolox, a potent antioxidant. In the ABTS assay, both the ethyl acetate and ethanol extracts of $H$. zeyheri had an $\mathrm{IC}_{50}$ value $(<20 \mu \mathrm{g} / \mathrm{ml})$ comparable to methanol extracts of $H$. procumbens $(19.8 \mu \mathrm{g} / \mathrm{ml})$ [17] in DPPH assay, which suggests that the former has better antioxidant properties than previously reported $[9,28]$. The
Table 4 Inhibitory activities of three extracts of $H$. zeyheri on the expression of cytokines (TNF-a, IL10) and cell viability in human U937 macrophages at $50 \mu \mathrm{g} / \mathrm{mL}$ concentration

\begin{tabular}{llll}
\hline Extract & TNF-a $(\mathbf{p g} / \mathrm{mL})$ & IL-10 (pg/mL) & Cell viability (\%) \\
\hline Ethyl acetate & $47.92 \pm 0.69^{\mathrm{a}}$ & $7.95 \pm 0.05^{\mathrm{a}}$ & $98.96 \pm 2.16^{\mathrm{a}}$ \\
Ethanol & $164.07 \pm 0.74^{\mathrm{b}}$ & $8.63 \pm 0.37^{\mathrm{a}}$ & $99.27 \pm 4.02^{\mathrm{a}}$ \\
Water & $217.13 \pm 3.24^{\mathrm{c}}$ & $8.06 \pm 0.48^{\mathrm{a}}$ & $99.97 \pm 2.48^{\mathrm{a}}$ \\
Diclofenac & $44.49 \pm 6.62^{\mathrm{a}}$ & $8.42 \pm 0.30^{\mathrm{a}}$ & $25.11 \pm 1.24^{\mathrm{b}}$ \\
Quercetin & $73.06 \pm 1.94^{\mathrm{d}}$ & $31.55 \pm 2.69^{\mathrm{b}}$ & $49.48 \pm 5.51^{\mathrm{c}}$ \\
\hline
\end{tabular}

Values with different superscript letters in each column are significantly different at $p<0.05$

similarity in antioxidant activity of $H$. procumbens to this study's results can be attributed to common glycosides such as harpagoside that are found in both $H$. zeyheri and $H$. procumbens.

In this study, the ethyl acetate and ethanol extract inhibited the production of NO in LPS stimulated mouse macrophages as demonstrated by the $\mathrm{IC}_{50}$ values below $100 \mu \mathrm{g} / \mathrm{ml}$. Further, although the inhibition of NO in the extracts was weaker relative to diclofenac and quercetin, the crude extracts of $H$. zeyheri showed the ability to inhibit inflammatory mediators, an indication of potentially good anti-inflammatory properties. However, in dose-dependence tests, inhibition of $\mathrm{NO}$ by the ethyl acetate extract was comparable to that of diclofenac and quercetin at concentrations of $100 \mu \mathrm{g} / \mathrm{ml}$ and $50 \mu \mathrm{g} / \mathrm{ml}$. In addition, the inhibition of TNF- $\alpha$ by the ethyl acetate extract was like diclofenac. Diclofenac has been shown to suppress pro-inflammatory mediators such as $\mathrm{NO}$ and TNF- $\alpha$ as part of its mode of action [2]. In this study, the ability of $H$. zeyheri to inhibit the proinflammatory cytokine in a similar way to diclofenac shows the potential of the extract for further exploration as an alternative. These findings also correspond with in vitro studies on the anti-inflammatory action of $H$. procumbens, which showed inhibition of inflammation mediators such as LOX, TNF, IL-6, IL-1 $\beta$, prostaglandin

Table 3 Dose-dependent activities of the three extracts of $H$. zeyheri on nitric oxide production inhibition and cell viability in RAW 246 mouse macrophages

\begin{tabular}{lllllll}
\hline & Concentration & Ethyl acetate & Ethanol & Water & Diclofenac & Quercetin \\
\hline NO & 100 & $62.84 \pm 2.66^{\mathrm{a}}$ & $53.87 \pm 2.56^{\mathrm{b}}$ & $27.01 \pm 4.23^{\mathrm{c}}$ & $68.26 \pm 0.81^{\mathrm{a}}$ & $69.05 \pm 1.46^{\mathrm{a}}$ \\
& 50 & $41.68 \pm 3.22^{\mathrm{a}}$ & $29.34 \pm 2.05^{\mathrm{b}}$ & $9.24 \pm 2.05^{\mathrm{c}}$ & $65.31 \pm 0.31^{\mathrm{a}}$ & $68.59 \pm 0.51^{\mathrm{a}}$ \\
& 25 & $24.67 \pm 5.81^{\mathrm{a}}$ & $17.92 \pm 5.73^{\mathrm{b}}$ & $8.03 \pm 3.29^{\mathrm{c}}$ & $60.09 \pm 1.15^{\mathrm{a}}$ & $57.27 \pm 0.98^{\mathrm{a}}$ \\
& 12.5 & $14.45 \pm 7.48^{\mathrm{a}}$ & $14.10 \pm 6.39^{\mathrm{a}}$ & $7.38 \pm 5.63^{\mathrm{b}}$ & $49.77 \pm 1.08^{\mathrm{c}}$ & $40.62 \pm 0.01^{\mathrm{c}}$ \\
& 100 & $60.65 \pm 3.02^{\mathrm{a}}$ & $85.90 \pm 4.26^{\mathrm{a}}$ & $102.97 \pm 3.40^{\mathrm{a}}$ & $1.12 \pm 0.38^{\mathrm{b}}$ & $27.97 \pm 2.08^{\mathrm{c}}$ \\
& 50 & $90.91 \pm 5.85^{\mathrm{a}}$ & $96.68 \pm 0.73^{\mathrm{a}}$ & $111.17 \pm 4.75^{\mathrm{a}}$ & $2.98 \pm 0.02^{\mathrm{b}}$ & $34.72 \pm 0.17^{\mathrm{c}}$ \\
& 25 & $88.95 \pm 3.50^{\mathrm{a}}$ & $96.72 \pm 1.33^{\mathrm{a}}$ & $90.79 \pm 3.16^{\mathrm{a}}$ & $7.57 \pm 1.16^{\mathrm{b}}$ & $59.15 \pm 6.52^{\mathrm{a}}$ \\
& 12.5 & $89.98 \pm 6.56^{\mathrm{a}}$ & $98.32 \pm 3.48^{\mathrm{a}}$ & $95.95 \pm 4.26^{\mathrm{a}}$ & $15.57 \pm 1.09^{\mathrm{b}}$ & $86.98 \pm 0.03^{\mathrm{a}}$ \\
& & & & &
\end{tabular}

Values with different superscript letters in each row are significantly different at $p<0.05$ 
PGE2 in LPS induced human and animal cell lines [1, 5, $16,23,27]$. Indeed, $H$. zeyheri and $H$. procumbens share common active ingredients which include harpagoside, harpagide, and verbascoside [27] hence the similarities in activity between the two species. In addition, the very low levels of human IL-10 expression in extracts of $H$. zeyheri relative to quercetin but like diclofenac, together with the strong correlation between these findings and the medicinal use of the plant by local communities in inflammatory-related disorders, confirm the possible mode of action of $H$. zeyheri that is similar to diclofenac.

Relative to the other extracts, the water extract showed no antioxidant activity in both the DPPH and ABTS assay. However, Devil's Claw extracts are particularly rich in water-soluble antioxidants [6], and the roots are generally administered orally in powdered form in traditional medicine. Further, Zhang et al. [50] showed that hydrolysis of the glycosidic bonds of harpagide and harpagoside products of Devil's Claw was a prerequisite step for activity. In their study, anti-inflammatory activity was significant in hydrolysed products of the iridoid glycosides, harpagide, and harpagoside, relative to the unhydrolysed compounds [50]. Thus, the lack of activity in water extracts may suggest problems associated with interference in the assays but may also confirm that the ethyl acetate extract was a superior extractant as compared to water.

Medicinal plants, due to their natural origin, are receiving growing attention as they are deemed to be much safer than many conventional drugs and are often used without medical supervision. Indeed, we found that $H$. zeyheri extracts had limited toxicity on the cells relative to diclofenac and quercetin. Thus, the inhibitory effect of $H$. zeyheri extracts in both the mouse and human macrophages assays was not due to cell death. Likewise, studies on $H$. zeyheri's taxonomic ally, $H$. procumbens, showed low cell toxicity in animal experiments [11]. In contrast, diclofenac had significant cell death suggesting that the inhibitory effect of diclofenac may also be due to cell death. That $H$. zeyheri had lower cell toxicity levels than diclofenac even at high concentrations, not only suggest that low toxicity may be a general property of Harpagophytum extracts but also lends support to the notion that natural products derived from plants may be safer than NSAIDs [10, 12]. Nonetheless, some studies have reported Harpagophytum to cause adverse effects such as mild gastrointestinal upset such as bloating, dyspepsia, and loss of taste [8], but at recommended doses, Harpagophytum seems to be well-tolerated [10]. However, given the limited amount of comparable data in the literature regarding $H$. zeyheri, there is a need to remain conservative in the interpretation of these findings and suggest the need for more research on this species.
Nonetheless, our findings have important implications for the medicinal value and conservation of this plant.

\section{Conclusions}

In conclusion, crude extracts of $H$. zeyheri exhibited strong antioxidant (radical scavenging of DPPH and ABTS) and anti-inflammatory (inhibition of TNF- $\alpha$ and NO) properties. Results obtained on $H$. zeyheri were comparable to an extensively studied close taxonomic species, $H$. procumbens. More specifically, the ethyl acetate extract proved to be the most effective radical scavenger extract in the DPPH and ABTS assays, thus a potentially attractive antioxidant. The ethyl acetate extract further displayed the highest inhibition of the production of NO and TNF- $\alpha$, respectively, and displayed comparability in inhibition to diclofenac at some concentrations. However, extracts of $H$. zeyheri were associated with low levels of human-IL-10 expression. All the crude extracts of $H$. zeyheri had low cell toxicity compared to diclofenac. Overall, these results provide evidence of the beneficial medicinal properties of $H$. zeyheri against inflammation. However, given the limited research conducted to date on the species, further studies on the molecular mechanism of action and use of animal models for action and toxicity as well as chemical composition responsible for activity, are required to further elucidate the action of $H$. zeyheri.

\section{Abbreviations}

DPPH: 2,2'-diphenyl-1-picrylhydrazy; ABTS: 2,2'-12 azino-bis (3ethylbenzothiazoline-6-sulphonic acid); 15-LOX: 15-lipoxygenase; NO: Nitric oxide; LPS: Lipopolysaccharide; MTT: 3-(4, 5-dimethylthiazol- 2-yl)-2,5-diphenyl tetrazolium bromide

\section{Acknowledgments}

The National University of Science and Technology (NUST) and Higherlife Foundation (HLF) provided the funding for the project (NUST (Grant RB/58/ 16); HLF(NCU56422B)). The Hwange Rural District council, Hwange community leadership, and community members granted permission to collect samples in the district and assisted. Anthony Mapaura, Senior Research officer at the National Herbarium and Botanic Garden in Zimbabwe did the formal identification of the plant and a voucher specimen is deposited there (Voucher: CASSRGH108539). The University of Pretoria's Phytomedicine Programme availed the laboratory facilities to conduct the experimental work.

\section{Authors' contributions}

S. N participated in the design of the study, carried out the field and laboratory work, and prepared the manuscript. L. M participated in the supervision of the laboratory work and manuscript revision. E. N participated in assistance in conducting the laboratory work and manuscript revision. $\mathrm{H}$. N, P. M, and S. S participated in the overall supervision of the design of the study, providing technical advice and revision of the manuscript. The author(s) read and approved the final manuscript.

\section{Authors' information}

S. N is a PhD student in the Forest Resources and Wildlife Management Department (FRWM) at the National University of Science and Technology (NUST). L. M is a Professor and leader of the Phytomedicine Program, Department of Paraclinical Sciences, at the University of Pretoria. E. N was a Post-Doctoral Fellow at the Phytomedicine Program, Department of Paraclinical Sciences, University of Pretoria, during the time of the study and is currently a Research Scientist at the Institute of Pharmacy, Martin-Luther 
University of Halle-Wittenberg (Germany). H. N and P. M are both in the Forest Resources and Wildlife Department at NUST, with the former being an Associate Professor and the latter a full Professor. S. S is Associate Professor in the Applied Chemistry Department at NUST.

\section{Funding}

This manuscript is part of a PhD project supported by a grant (Grant: RB/58/ 16) from the Research Board of the National University of Science and Technology, Zimbabwe and Higherlife Foundation Delta Philanthropies Doctoral Fellowship (NCU56422B).

\section{Availability of data and materials}

All data generated and used to support the findings of this study are adequately contained within the manuscript.

\section{Declarations}

\section{Ethics approval and consent to participate}

Permission to collect tuber samples was sought from the Hwange Rural District Council, as well as the local leadership (Chief, Headman, and the Kraal heads) in the specific ward. The collection of the wild plant samples complied with the Forest Resources and Wildlife department's guidelines at the National University of Science and Technology. The procedure for sample collection, preservation, and laboratory analysis was reviewed by the department to ensure that there was compliance.

\section{Consent for publication}

Not applicable.

\section{Competing interests}

The authors declare that they have no financial or competing interest that may have influenced the writing of this manuscript.

\section{Author details}

'Department of Forest Resources and Wildlife Management, Faculty of Applied Science, National University of Science and Technology, P. O. Box AC 939, Ascot, Bulawayo, Zimbabwe. ${ }^{2}$ Phytomedicine Programme, Department of Paraclinical Sciences, Faculty of Veterinary Science, University of Pretoria, Private Bag X04, Onderstepoort 0110, South Africa. ${ }^{3}$ Institute of Pharmacy, Martin Luther University, Halle-Wittenberg, 06099 Halle (Saale), Germany. ${ }^{4}$ School of Animal, Plant and Environmental Sciences, University of the Witwatersrand, Private Bag 3, Wits, Johannesburg 2050, South Africa. ${ }^{5}$ Department of Applied Chemistry, Faculty of Applied Science, National University of Science and Technology, P. O. Box AC 939, Ascot, Bulawayo, Zimbabwe.

\section{Received: 4 February 2021 Accepted: 29 August 2021}

\section{Published online: 23 September 2021}

\section{References}

1. Abdelouahab N, Heard CM. Effect of the major glycosides of Harpagophytum procumbens (Devil's claw) on epidermal cyclooxygenase2(COX-2) in vitro. J Nat Prod. 2008;71(5):746-9. https://doi.org/10.1021/ np070204u.

2. Al-Armin MM, Uddin MM, Rahman MM, et al. Effect of diclofenac and antidepressants on the inflammatory response in astrocyte cell culture. Inflammopharmacology. 2013;21(6):421-5. https://doi.org/10.1007/s10787013-0181-9.

3. Baghdikian B, Lanhers MC, Fleurentin J, Ollivier E, Maillard C, Balansard G, et al. An analytical study and anti-inflammatory and analgesic effects of Harpagophytum procumbens and Harpagophytum zeyheri. Planta Med. 1997; 63(02):171-6. https://doi.org/10.1055/s-2006-957638.

4. Beg S, Swain S, Hasan H, Barkat MA, Hussain MS. Systematic review of herbals as potential anti-inflammatory agents: recent advances, current clinical status and future perspectives. Pharmacogn Rev. 2011;5(10):120-37. https://doi.org/10.4103/0973-7847.91102.

5. Benito PB, Lanza AMD, Sen AMS, Galindez JDS, Matellano LF, Gómez AS, et al. Effects of some iridoids from plant origin on arachidonic acid metabolism in cellular systems. Planta Med. 2000;66(04):324-8. https://doi. org/10.1055/s-2000-8549.
6. Betancor-Fernández A, Pérez-Gálvez A, Sies H, Stahl W. Screening pharmaceutical preparations containing extracts of turmeric rhizome, artichoke leaf, devil's claw root and garlic or salmon oil for antioxidant capacity. J Pharm Pharmacol. 2003;55(7):981-6. https:/doi.org/10.1211/0022357021468.

7. Brendler T. From Bush Medicine to Modern Phytopharmaceutical: A Bibliographic Review of Devil's Claw (Harpagophytum spp.). Pharmaceuticals. 2021;14(8):726. https://doi.org/10.3390/ph14080726.

8. Brendler T, Gruenwald J, Ulbricht C, Basch E. Devil's claw (Harpagophytum procumbens DC) an evidence-based systematic review by the natural standard research collaboration. J Herb Pharmacother. 2006;6(1):89-126.

9. Chantre P, Cappelaere A, Leblan D, Guedon D, Vandermander J, Fournie B. Efficacy and tolerance of Harpagophytum procumbens versus diacerhein in treatment of osteoarthritis. Phytomedicine. 2000;7(3):177-83. https://doi. org/10.1016/S0944-7113(00)80001-X.

10. Chrubasik S, Künzel O, Thanner J, Conradt C, Black A. A 1-year follow-up after a pilot study with Doloteffin ${ }^{\oplus}$ for low back pain. Phytomedicine. 2005; 12(1-2):1-9. https://doi.org/10.1016/j.phymed.2004.01.005.

11. Chrubasik S, Conradt C, Black A. The quality of clinical trials with Harpagophytum procumbens. Phytomedicine. 2003;10(6-7):613-23. https:// doi.org/10.1078/094471103322331647.

12. Chrubasik S, Thanner J, Kunzel O, Conradt C, Pollak ABS. Comparison of outcome measures during treatment with the proprietary Harpagophytum extract Doloteffin (registered) in patients with pain in the lower back, knee or hip. Phytomedicine. 2002;9(3):181-94. https://doi.org/10.1078/0944-711300140.

13. Do QD, Angkawijaya AE, Tran-Nguyen PL, Huynh LH, Soetaredjo FE, Ismadji $S$, et al. Effect of extraction solvent on total phenol content, total flavonoid content, and antioxidant activity of Limnophila aromatic. J Food Drug Anal. 2014;22(3):296-302. https://doi.org/10.1016/j.jfda.2013.11.001.

14. Dzoyem JP, Tsamo AT, Melong R, Mkounga P, Nkengfack AE, McGaw LJ, et al. Cytotoxicity, nitric oxide and acetylcholinesterase inhibitory activity of three limonoids isolated from Trichilia welwitschii (Meliaceae). Biol Res. 2015; 48(1):57. https://doi.org/10.1186/s40659-015-0049-0.

15. European Union Herbal Monograph on Harpagophytum Procumbens DC. and/or Harpagophytum zeyheri Decne. Radix. Amsterdam: European Medicines Agency; 2016. p. 2-8.

16. Fiebich BL, Heinrich M, Hiller KO, Kammerer N. Inhibition of TNF-a synthesis in LPS-stimulated primary human monocytes by Harpagophytum extract SteiHap 69. Phytomedicine. 2001;8(1):28-30. https://doi.org/10.1078/0944-7113-00002.

17. Frum Y, Viljoen AM. In vitro 5-lipoxygenase and anti-oxidant activities of South African medicinal plants commonly used topically for skin diseases. Skin Pharmacol Physiol. 2006;19(6):329-35. https://doi.org/10.1159/0000952 53. Epub 2006 Aug 23.

18. Georgiev M, Alipieva K, Erdogan O, Ilkay. Cholinesterases inhibitory and antioxidant activities of Harpagophytum procumbens from in vitro systems. Phytother Res. 2012;26(2):313-6. https://doi.org/10.1002/ptr.3555.

19. Goci E, Shkeli R, Haloci E, Malaj L. Complementary and alternative medicine (CAM) for pain, herbal anti-inflammatory drugs. Eur Sci J. 2013;9:90-105.

20. Grant L, McBean DE, Fyfe L, Warnock AM. A review of the biological and potential therapeutic actions of Harpagophytum procumbens. Phytother Res. 2007;21(3):199-209. https://doi.org/10.1002/ptr.2029.

21. Grote, K. The increased harvest and trade of Devil's Claw (Harpagophytum procumbens) and its impacts on the people and environment of Namibia, Botswana and South Africa. Global Facilitation Unit for Underutilised Species, Italy. Available from: /http://www.underutilized-species.org/ documents/publications/devils_claw.pdfS (Accessed 10.07.16). 2003.

22. Handa SS, Khanuja S, Longo G, Rakesh DD. Extraction technologies for medicinal and aromatic plants, International centre for science and high technology; 2008. p. 21-5.

23. Jang MH, Lim S, Han SM, Park HJ, Shin I, Kim JW, et al. Harpagophytum procumbens suppresses lipopolysaccharide- stimulated expressions of cyclooxygenase-2 and inducible nitric oxide synthase in fibroblast cell line L929. J Pharmacol Sci. 2003;93(3):367-71. https://doi.org/10.1254/jphs.93.367.

24. Klein A, Eliakim R. Non-steroidal anti-inflammatory drugs and inflammatory bowel disease. Pharmaceuticals. 2010;3(4):1084-92. https://doi.org/10.3390/ ph3041084.

25. Lanas A, Sopeña F. Nonsteroidal anti-inflammatory drugs and lower gastrointestinal complications. Gastroenterol Clin N Am. 2009;38(2):333-52. https://doi.org/10.1016/j.gtc.2009.03.007.

26. Mantovani A, Allavena P, Sica A, Balkwill F Cancer-related inflammation. Nature. 2008;454(7203):436-44. https://doi.org/10.1038/nature07205. 
27. McGregor G, Fiebich B, Wartenberg A, Brien S, Lewith G, Wegener T. Devil's claw (Harpagophytum procumbens): an anti-inflammatory herb with therapeutic potential. Phytochem Rev. 2005;4(1):47-53. https://doi.org/10.1 007/s11101-004-2374-8.

28. Mncwangi NP, Chen W, Vermaak I, Viljoen AM, Gericke N. Devil's claw- a review of the ethnobotany, phytochemistry and biological activity of Harpagophytum procumbens. J Ethnopharmacol. 2012;143(3):755-71. https:// doi.org/10.1016/j.jep.2012.08.013.

29. Mosmann T. Rapid colorimetric assay for cellular growth and survival: application to proliferation and cytotoxicity assays. J Immunol Methods. 1983;16(1-2):55-63. https://doi.org/10.1016/0022-1759(83)90303-4.

30. Mundy PJ, Ncube SF. Devil's claw - a natural substitute for diclofenac? Vulture News. 2014;67(2):43-7. https://doi.org/10.4314/vulnew.v67i2.

31. Muzila M. Genetic, morphological and chemical variation in the genus Harpagophytum. Uppsala: Doctoral Thesis, Swedish University of Agricultural Sciences; 2016.

32. Passmore JS, Lukey PT, Ress SR. The human macrophage cell line U937 as an in vitro model for selective evaluation of mycobacterial antigen-specific cytotoxic T-cell function. Immunology. 2001;102(2):146-56. https://doi.org/1 0.1046/j.1365-2567.2001.01164.x.

33. Pohanka M, Sobotka J, Svobodova H, Stetina R. Investigation of oxidative stress in blood, brain, kidney, and liver after oxime antidote HI-6 application in a mouse experimental model. Drug Chemical Toxicology. 2011;34(3):25560. https://doi.org/10.3109/01480545.2010.542753.

34. Re R, Pellegrini N, Proteggente A, Pannala A, Yang M, Rice-Evans C. Antioxidant activity applying an improved ABTS radical cation decolorization assay. Free Radic Biol Med. 1999;26(9-10):1231-7. https://doi. org/10.1016/S0891-5849(98)00315-3.

35. Riciotti E, Fitzgerald GA. Prostaglandins and inflammation. Arterioscler Thromb Vasc Biol. 2011;31(5):986-1000. https://doi.org/10.1161/ATVBAHA.11 0.207449 .

36. Sagnia B, Fedeli D, Casetti R, Montesano C, Falcioni G, Colizzi V. Antioxidant and anti-Inflammatory activities of extracts from Cassia alata, Eleusine indica, Eremomastax speciosa, Carica papaya and Polyscias fulva medicinal plants collected in Cameroon. PloS one. 2014;9:E103999.

37. Schneider E, Sanders J, von Willert D. Devil's claw (Harpagophytum procumbens) from southern Africa. Sustainable use by cultivation combined with controlled harvesting in semiwild populations. In: Bogers RJ, Craker LE, Lange D, editors. Medicinal and aromatic plants. Berlin: Springer; 2006. p. 181-202. https://doi.org/10.1007/1-4020-5449-1_13.

38. Sharma JN, Mohammed LA. The role of leukotrienes in the pathophysiology of inflammatory disorders: is there a case for revisiting leukotrienes as therapeutic targets? Inflammopharmacology. 2006;14(1-2):10-6. https://doi. org/10.1007/s10787-006-1496-6.

39. Shimada K, Fujikawa K, Yahara K, Nakamura T. Antioxidative properties of xanthan on the autoxidation of soybean oil in cyclodextrin emulsion. J Agric Food Chem. 1992:40:945-8.

40. Shultz S, Baral HS, Charman S, Cunningham AA, Das D, Ghalsasi GR, et al. Diclofenac poisoning is widespread in declining vulture populations across the Indian subcontinent. Proc Royal Soc London B. 2004;271(suppl_6):S45860. https://doi.org/10.1098/rsbl.2004.0223.

41. Simon JE, Koroch AR, Acquaye D, Jefthas E, Juliani R, Govindasamy R. Medicinal crops of Africa. In: Janick J, Whipkey A, editors. Issues in new crops and new uses. Alexandria: ASHS Press; 2007.

42. Stewart KM, Cole D. The commercial harvest of devil's claw (Harpagophytum spp.) in southern Africa: the devil's claw in the details. J Ethnopharmacol. 2005;100(3):225-36. https://doi.org/10.1016/j.jep.2005.07.004.

43. Strohbach M, Cole D. Population dynamics and sustainable harvesting of the medicinal plant Harpagophytum procumbens in Namibia. BfN Skripten. 2007:203:59.

44. Turner MD, Nedjai B, Hurst T, Pennington DJ. Cytokines \& Chemokines. At the crossroads of cell signalling and inflammatory disease. BBA-Molecular Cell Research. 2014;18643:2563-82.

45. Van Wyk BE, Van Oudtshoorn B, Gericke N. Medicinal plants of South Africa. Briza: Publications, Pretoria; 1997.

46. Wang Y, Feinstein SI, Manevich Y, Ho YS, Fisher AB. Lung injury and mortality with hyperoxia are increased in peroxiredoxin 6 gene-targeted mice. Free Radic Biol Med. 2004:37:1736-43.

47. Wolf AM, Wolf D, Rumpold H, Ludwiczek S, Enrich B, Gastl G, et al. The kinase inhibitor Imatinib Mesylate inhibits TNF-a; production invitro and prevents TNF-dependent acute hepatic inflammation. Proc Nat Acad Sci. 2005:102:13622-7.

48. Yang EJ, Yim EY, Song G, Kim GO, Hyun CG. Inhibition of nitric oxide production in lipopolysaccharide-activated RAW 264.7 macrophages by Jeju plant extracts. Interdiscip Toxicol. 2009;2:245-9.

49. Zhang JM, An J. Cytokines, inflammation, and pain. International anesthesiology clinics. 2007:45:27-37.

50. Zhang L, Feng L, Jia Q, Xu J, Wang R, Wang Z, et al. Effects of $\beta$ glucosidase hydrolyzed products of harpagide and harpagoside on cyclooxygenase-2 (COX-2) in vitro. Bioorg Med Chem. 2011;19:4882-3886.

\section{Publisher's Note}

Springer Nature remains neutral with regard to jurisdictional claims in published maps and institutional affiliations.
Ready to submit your research? Choose BMC and benefit from:

- fast, convenient online submission

- thorough peer review by experienced researchers in your field

- rapid publication on acceptance

- support for research data, including large and complex data types

- gold Open Access which fosters wider collaboration and increased citations

- maximum visibility for your research: over $100 \mathrm{M}$ website views per year

At BMC, research is always in progress.

Learn more biomedcentral.com/submissions 